\title{
Giant sperm in a Neotropical moth Xenosoma geometrina (Lepidoptera: Arctiidae)
}

\author{
EDWARD H. MORROW \\ Population and Evolutionary Biology Research Group, School of Biological Sciences, Nicholson Building, University of Liverpool, \\ Liverpool, L693BX, UK; e-mail: ehmorrow@liv.ac.uk
}

Key words. Lepidoptera, Arctiidae, Xenosoma, eupyrene, apyrene, sperm size, sperm competition, Costa Rica

\begin{abstract}
The stereotypical sperm is characterised as being tiny but produced in great quantities. However a few species (frequently insects) produce much larger spermatozoa, probably with an associated cost in reduced numbers per ejaculate. Here I present the first evidence that a species within the Lepidoptera also produces giant sperm. It seems likely that given wider sampling this record for the largest sperm produced by a lepidopteran may subsequently be broken.
\end{abstract}

\section{INTRODUCTION}

Spermatozoa are usually envisaged as being tiny and numerous (Parker, 1982) however there is wide variation around this theme (Sivinski, 1980; Cummins \& Woodall, 1985; Gage, 1998). There are a handful of examples from the animal kingdom of sperm gigantism, that is extremely long sperm. Most of these examples come from insects: $10 \mathrm{~mm}$ in Divales bipustulatus (Coleoptera: Cleridae) (Mazzini, 1976); $15 \mathrm{~mm}$ in Notonecta glauca (Hemiptera: Notonectidae) (Afzelius et al., 1976). The Drosophilidae (Diptera) exhibit the most spectacular range of sizes from less than $1 \mathrm{~mm}$ to over $58 \mathrm{~mm}$ (Pitnick et al., 1995).

The function of these giant gametes remains unclear. Spermatozoa are not cost-free to produce and the production of giant sperm is apparently traded off against sperm numbers (Pitnick \& Markow, 1994a) or delayed maturity (Pitnick et al., 1995). Theory predicts that any advantages in producing such large sperm have little to do with providing resources to the developing zygote (Parker, 1982). Indeed Pitnick \& Karr (1998) have found that the tails of fertilizing sperm persist throughout embryogenesis in Drosophila species and are sequestered within the midguts of the developing larvae. They are later defecated by the larvae after hatching. The elongate flagellum may function in the mechanics of sperm storage or fertilisation. There is some evidence that the dimensions of the female reproductive tract may influence the evolution of sperm size, sperm may be selected according to their ability to compete for or remain within a female's sperm storage organ (Presgraves et al., 1999). Alternatively the complex helical arrangement that some flagella exhibit within the egg may play a role in how the sperm cell enters the egg or in the subsequent physical organisation of the developing zygote (Karr \& Pitnick, 1996).

Lepidoptera are unusual in producing two types of sperm (Meves, 1902), sterile apyrene sperm and fertile eupyrene sperm. The ultrastructure and path of development of these two morphs differ considerably (Philips, 1971; Friedländer, 1997). The primary function of the eupyrene sperm is to unite the male haplotype with the ova. Although the function of the apyrene sperm is not definitely known, recent evidence suggests that it may function in delaying female receptivity as originally proposed by Silberglied et al. (1984) (Cook \& Wedell, 1999). The lengths of these two lepidopteran sperm morphs have been shown to vary considerably across species, but not to the same degree as the fertilising sperm of other insect groups: apyrene sperm range from $216-756 \mu \mathrm{m}$ and eupyrene from $345-1,545$ $\mu \mathrm{m}$ (Gage, 1994). Here I examine eupyrene, apyrene and testis size from Xenosoma geometrina (Schaus, 1910). This species is an arctiid moth resident in pre-montane forests of southern Costa Rica. I also present evidence for a new record in sperm size within the Lepidoptera of approximately $12 \mathrm{~mm}$. This is similar to the adult animal's total body length, and may therefore be classified as a sperm giant.

\section{MATERIAL AND METHODS}

Moths were sampled using a UV lamp and sheet at the Las Cruces (San Vito) Field Station, Costa Rica during June and July 1998. Individual moths were identified from the literature (Schaus, 1910; Seitz, 1925) and by comparison with named specimens in collections at the Natural History Museum, London, UK and the Instituto Nacional de Biodiversidad (INBIO), Costa Rica.

All moths were frozen within a few hours of capture and their body mass measured in grams. Volume of the single spherical fused testes was calculated from the mean of three equidistant diameter measures after microdissection using a binocular microscope fitted with an eye-piece graticule.

Mature sperm were recovered from the distal portion of the vasa deferentia where mature bundles of eupyrene and disassociated apyrene sperm are stored (Norris, 1932; Drummond, 1984). Sperm samples were dispersed in distilled water and then air-dried as smears on glass slides. Phase contrast microscope images of up to 3 eupyrene bundles and 5 individual apyrene sperm from each male were relayed to a video monitor where they could be traced onto acetate sheets. Images of these tracings were measured using a digital map-measurer. The extreme length of the bundles of eupyrene sperm makes their manipulation difficult, but it is easy to identify which bundles have been broken during slide preparation. Intact bundles have a smooth tapering at either end whereas broken bundles terminate abruptly with a "squared-off" end. This method of measuring sperm length is repeatable both between measures (repeated measures $\mathrm{GLM}, \mathrm{F}=155033, \mathrm{n}=20, \mathrm{P}<0.001$ ) and between observers (repeated measures GLM, $\mathrm{F}=184189, \mathrm{n}=10, \mathrm{P}<$ $0.001)$.

\section{RESULTS AND DISCUSSION}

Xenosoma geometrina is a small moth, with a mean male forewing length of $20.3 \mathrm{~mm}( \pm 1.0$ s.e., $\mathrm{n}=7)$ and mean male 


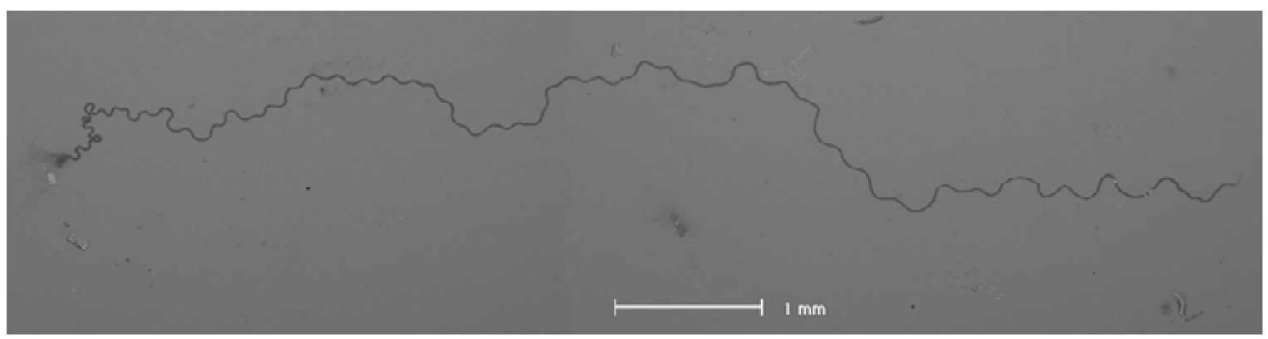

Fig. 1. Scanning electron micrograph (BSE) showing a single eupyrene sperm bundle from Xenosoma geometrina. Scale bar: 1 $\mathrm{mm}$.

body mass of $0.08 \mathrm{~g}( \pm 0.02, \mathrm{n}=7)$. Mean eupyrene sperm length (Fig. 1) was found to be $12,249 \mu \mathrm{m}( \pm 405.3, \mathrm{n}=7 \mathrm{sperm}$, 5 males) which is comparable with total adult body length and exceeds the previous published record for sperm size in the Lepidoptera by over $10 \mathrm{~mm}(1,545 \mu \mathrm{m}$ produced by Dryas julia (Gage, 1994)]. Mean apyrene length was considerably less than eupyrene length $(2,153 \mu \mathrm{m} \pm 19.0, \mathrm{n}=35$ sperm, 7 males $)$ but it also exceeds the same record. In contrast the testes are not particularly large when compared with other lepidopterans (Gage, 1994). Mean testis volume in $X$. geometrina was $8.5 \mathrm{~mm}^{3}$ $( \pm 1.38, \mathrm{n}=7)$ with mean testis diameter of $1.2 \mathrm{~mm}( \pm 0.07, \mathrm{n}=$ 7). Eupyrene sperm length is thus an order of magnitude longer than the maximum diameter of the testes in which they develop and mature, and the developing eupyrene sperm bundles may be highly folded or coiled within the follicles of the testis.

The function of giant sperm remains unexplained. However, males cannot produce sperm without incurring some cost (Dewsbury, 1982) and models predict that if sperm compete numerically for fertilisations (Parker, 1970) then sperm numbers should be increased within an ejaculate at the expense of sperm size (Parker \& Begon, 1993). There may also be other costs associated with the evolution of extremely long sperm such as reduced sperm production and a lag in time to maturity (Pitnick et al., 1995). Pitnick \& Markow (1994b) identified four selective factors which may be important in the evolution of sperm size: selection to prevent hybridisation, paternal investment in offspring by provisioning of gametes, sperm competition, and selection by the environment of the female reproductive tract. There is growing evidence that both the intensity or level of sperm competition experienced by males in a species and female mediation of sperm storage or usage are important factors in the evolution of sperm length [see Briskie et al. (1997) for a further discussion of this].

Further investigation is warranted of sperm size within the Lepidoptera as it seems likely that other species may produce even larger gametes. Correspondingly, investigations of the female reproductive tract morphology and mating system within this and other species will be essential in understanding the evolution of sperm size.

ACKNOWLEDGEMENTS. I am very grateful to D. Hosken and M. Gage for providing helpful comments on the manuscript. I also thank L. Diego Gómez and staff of the Organisation for Tropical Studies; D. Goodger and G. Martin at the Natural History Museum (London); and I. Chacón at INBIO (Costa Rica). C.J. Veltkamp provided the micrograph. This work was supported by a NERC studentship with permission for collection from the Ministerio del Ambiente y Energia (Costa Rica) permit number 27087321.

\section{REFERENCES}

Afzelius B.A., Baccetti B. \& Dallai R. 1976: The giant spermatozoon of Notonecta. J. Submicr. Cytol. 8: 149-161.
Briskie J.V., Montgomerie R. \& BirkHead T.R. 1997: The evolution of sperm size in birds. Evolution 51: 937-945.

Cook P.A. \& Wedell N. 1999: Non-fertile sperm delay female remating. Nature (London) 397: 486.

Cummins J.M. \& Woodall P.F. 1985: On mammalian sperm dimensions. J. Reprod. Fert. 75: 153-175.

Dewsbury D.A. 1982: Ejaculate cost and male choice. Am. Nat. 119: $601-610$.

DRUMMOND B.A. 1984: Multiple mating and sperm competition in the Lepidoptera. In Smith R.L. (ed.): Sperm Competition and the Evolution of Animal Mating System. Academic Press, London, pp. 291-370.

FRIEDLÄNDER M. 1997: Control of the eupyrene-apyrene sperm dimorphism in Lepidoptera. J. Insect Physiol. 43: 1085-1092.

GAGE M.J.G. 1994: Associations between body size, mating pattern, testis size and sperm lengths across butterflies. Proc. $R$. Soc. Lond. (B) 258: 247-254.

Gage M.J.G. 1998: Mammalian sperm morphometry. Proc. R. Soc. Lond. (B) 265: 97-103.

KarR T.L. \& PItNick S. 1996: The ins and outs of fertilization. Nature (London) 379: 405-406.

MazzINI M. 1976: Giant spermatozoa in Divales bipustulatus F. (Coleoptera: Cleridae). Int. J. Insect Morphol. Embryol. 5: 107-115.

Meves F. 1902: Uber oligopyrene und apyrene Spermien und über ihre Entstehung, nach Beobachtungen an Paludina und Pygaera. Arch. Mikrosk. Anat. 61: 1-84.

NorRIS M.J. 1932: Contributions towards the study of insect fertility. I. The structure and operation of the reproductive organs of the genera Ephestia and Plodia (Lepidoptera: Phycitidae). Proc. Zool. Soc. Lond. 1932: 595-611.

PARKER G.A. 1970: Sperm competition and its evolutionary consequences in the insects. Biol. Rev. 45: 525-567.

PARKer G.A. 1982: Why are there so many tiny sperm? Sperm competition and the maintenance of two sexes. J. Theor. Biol. 96: 281-294.

Parker G.A. \& Begon M.E. 1993: Sperm competition games: sperm size and number under gametic control. Proc. R. Soc. Lond. (B) 253: 255-262.

PHILIPS D.M. 1971: Morphogenesis of the lacinate appendages of lepidopteran spermatozoa. J. Ultrastruct. Res. 34: 567-585.

Pitnick S. \& KarR T.L. 1998: Paternal products and by-products in Drosophila development. Proc. R. Soc. Lond. (B) 265 : 821-826.

Pitnick S. \& MARKow T.A. 1994a: Large-male advantages associated with costs of sperm production in Drosophila hydei, a species with giant sperm. Proc. Natn. Acad. Sci. USA 91: 9277-9281.

Pitnick S. \& MarKow T.A. 1994b: Male gametic strategies: sperm size, testes size, and the allocation of ejaculate among 
successive mates by the sperm-limited fly Drosophila pachea and its relatives. Am. Nat. 143: 785-819.

Pitnick S., Markow T.A. \& Spicer G.S. 1995: Delayed male maturity is a cost of producing large sperm in Drosophila. Proc. Natn. Acad. Sci. USA 92: 10614-10618.

Presgraves D.C., Baker R.H. \& Wilkinson G.S. 1999: Coevolution of sperm and female reproductive tract morphology in stalk-eyed flies. Proc. R. Soc. Lond. (B) 266: 1041-1047.

Schaus W. 1910: Eloria geometrina. Ann. Mag. Nat. Hist. 8: 408.
SEITZ A. 1925: The Macrolepidoptera of the World. Fauna Americana Vol. 6.

Silberglied R.E., Shepherd J.G. \& Dickinson J.L. 1984: Eunuchs: the role of apyrene sperm in lepidoptera? Am. Nat. 123: $255-265$.

SIVINSKI J. 1980: Sexual selection and insect sperm. Fla. Entomol. 60: 99-111.

Received August 9, 1999; accepted December 3, 1999 